\title{
First records of Parergodrilus heideri ("Polychaeta": Parergodrilidae) and Hrabeiella periglandulata ("Polychaeta": Hrabeiellidae) from Slovakia and new records of both species from Czechia
}

\author{
J. SCHLAGHAMERSKÝ ${ }^{1 *} \&$ M. BÍLKOVÁ ${ }^{1}$ \\ ${ }^{1}$ Jiři Schlaghamerský \& Martina Bílková, Masaryk University, Faculty of Science, Department of Botany \\ and Zoology, Kotlárská 2, 61137 Brno, Czech Republic \\ *Corresponding author: jiris@sci.muni.cz.
}

\begin{abstract}
In the course of a study on microannelids of spring fens and adjacent grasslands in the Western Carpathians (within Czechia and Slovakia), conducted in spring and autumn of 2015 and 2016, the two terrestrial, soil-dwelling polychaetes Parergodrilus heideri and Hrabeiella periglandulata were recorded for the first time in Slovakia at six sites and one site, respectively. The find of $P$. heideri in the eastern part of Slovakia represents the second eastern-most published record within its known European range (only a recent record from Estonia lies further in the east). Within Czechia, $P$. heideri (hitherto known from a single site in the north of Bohemia) was found at four sites and H. periglandulata at three sites, all in north-eastern Moravia close to the Polish and Slovak borders.
\end{abstract}

Keywords. Annelida, grassland, fen, wetland, Western Carpathians, soil fauna.

\section{INTRODUCTION}

$\mathrm{O}_{\mathrm{n}}^{\mathrm{n}}$ nly two truly soil-dwelling non-clitellate annelids are known, i.e. Parergodrilus heideri Reisinger, 1925 and Hrabeiella periglandulata Pižl \& Chalupský, 1984. Non-clitellate means that they have been traditionally placed in the taxon Polychaeta, which is, however, considered paraphyletic and therefore given in-between quotation marks elsewhere in this text. Also members of the Aeolosomatidae (formerly placed within the clitellate "Oligochaeta", now as one of the two taxa constituting Aphanoneura, also within "Polychaeta") are found in soil. However, these aeolosomatid species are apparently semiaquatic, being active in the water-filled soil pores, and the very same species are more frequently found in aquatic habitats. This is not the case with the above-mentioned species, though one of them, $P$. heideri, has also been found in water-logged soil and ground water (Martínez-Ansemil \& Parapar 2009, Stoch et al. 2011). After some confusion about its taxonomic position in the years after its description (Reisinger 1925), P. heideri was placed in the small family Parergodrilidae (Reisinger 1960) together with one other species, Stygocapitella subterranea Knöllner, 1934 (living in sediments of the marine littoral and in coastal groundwater).

There is no close phylogenetic relationship between the Parergodrilidae and $H$. periglandulata (Jördens et al. 2004). H. periglandulata had been listed in scientific works without assignation to any family, until Christoffersen (2012) formally erected the monotypic family Hrabeiellidae. For an up-to-date view on the phylogenetic position (yet not fully resolved) of the above-mentioned taxa see Weigert and Bleidorn (2016).

Both species were originally described from Central Europe: P. heideri from the vicinity of Graz in Styria, Austria (Reisinger 1925), H. periglandulata from South Bohemia, Czechia (Pižl \& Chalupský 1984). Since then our knowledge about their distribution has increased substantially. An overview of the occurrence of $P$. heideri in Europe was given by Rota et al. (2010). The species has been found from north-eastern Spain 
in the west to northern Croatia in the east and from southern Sweden in the north to southern Italy. Outside of Europe it was recorded in Korea (Dózsa-Farkas \& Hong 2010) and within North America in the states of Minnesota and Wisconsin, USA (Schlaghamerský \& Frelich 2012). An overview of our current knowledge on the occurrence of $H$. periglandulata in Europe was published by Dózsa-Farkas \& Schlaghamerský (2013), showing a distribution from north-western Spain in the west to north-western Romania in the east and from southern Sweden in the north to central Italy in the south. This work furthermore rejected ideas about the presence of more than one species in Europe, to be discriminated based on chaetal ultrastructure. Outside of Europe, H. periglandulata was also found at a site in Korea (Dózsa-Farkas \& Hong 2010). The publication of further finds of both species outside of Europe by the first author of the present paper is under preparation.

In the present paper we report on the first records of both species in Slovakia. In the case of $P$. heideri this is based on finds at multiple localities. Whereas $H$. periglandulata had been reported from five sites in three areas of Czechia, four of which are located in Bohemia and one in the eastern part of the country, in Moravia (Schlaghamerský \& Šídová 2009; Dózsa-Farkas \& Schlaghamerský 2013), P. heideri was hitherto known from a single locality in Czechia, more exactly the Giant Mountains (Krkonoše) in northern Bohemia (this single published record, lacking details on the locality, was rather hidden in a paper about the fauna of Enchytraeidae and Parergodrilidae of Sweden: Chalupský 1992). In the present paper we report on three additional sites of occurrence for each of the two species within Czechia, this time in eastern Moravia, close to the Slovak and Polish border. The fact that we found both species at several sites and in considerable numbers also allows us to present some additional information and thoughts on the species' habitat preferences.

\section{MATERIAL AND METHODS}

Specimens of both species were found during a large scale sampling of annelids of non-forest micro-wetlands (spring fens of different levels of $\mathrm{pH}$ and mineral richness) and adjacent grasslands (meadows or pastures) in the Western Carpathians, conducted in 2015 and 2016 in the easternmost part of Czechia and a substantial part of Slovakia. This included 21 pairs of wetland and grassland in Slovakia, each sampled once in spring (April - May) and once in autumn (September - October). Microannelids were sampled by a cylinder-shaped steel corer with a circular area of $17 \mathrm{~cm}^{2}$ to the depth of 9-15 cm (depending of the penetrability of the sediments or soil). Five cores were taken at each site-habitat combination at each sampling date. The obtained cores were subdivided into $3-\mathrm{cm}$ thick layers. These were put in plastic bags and kept cool during transport and subsequent storage in the laboratory $\left(\right.$ at $\left.4{ }^{\circ} \mathrm{C}\right)$. Annelids were extracted by wet funnel extraction without heating $(48 \mathrm{~h}$, cooling by a water bath, retrieval of a first batch of extracted annelids and water replacement after the first 24 hours), sorted out under a preparatory binocular microscope, stored in water-filled Petri dishes (at $4{ }^{\circ} \mathrm{C}$, for a short time), and identified under a compound laboratory microscope. Due to the high number of enchytraeids in the samples, the processing of grassland soil cores from a given site was stopped when at least 140 microannelid specimens from at least five soil cores, covering both the spring and autumn seasons, were extracted and identified. Microannelid numbers in the wetland samples were substantially lower and thus all fen sediment cores were processed. The absolute numbers reported here for the two habitats, fen and grassland, are therefore not based on the same sampling effort.

\section{RESULTS}

The geographic situation of the sites where either of the two species was recorded is presented in Figure 1. For the geographic coordinates and further details about the localities and the numbers of recorded specimens see Table 1.

Parergodrilis heideri was found at six sites in Slovakia (31 specimens in total, all females) from the Kysuce Highlands in the north-west of the 


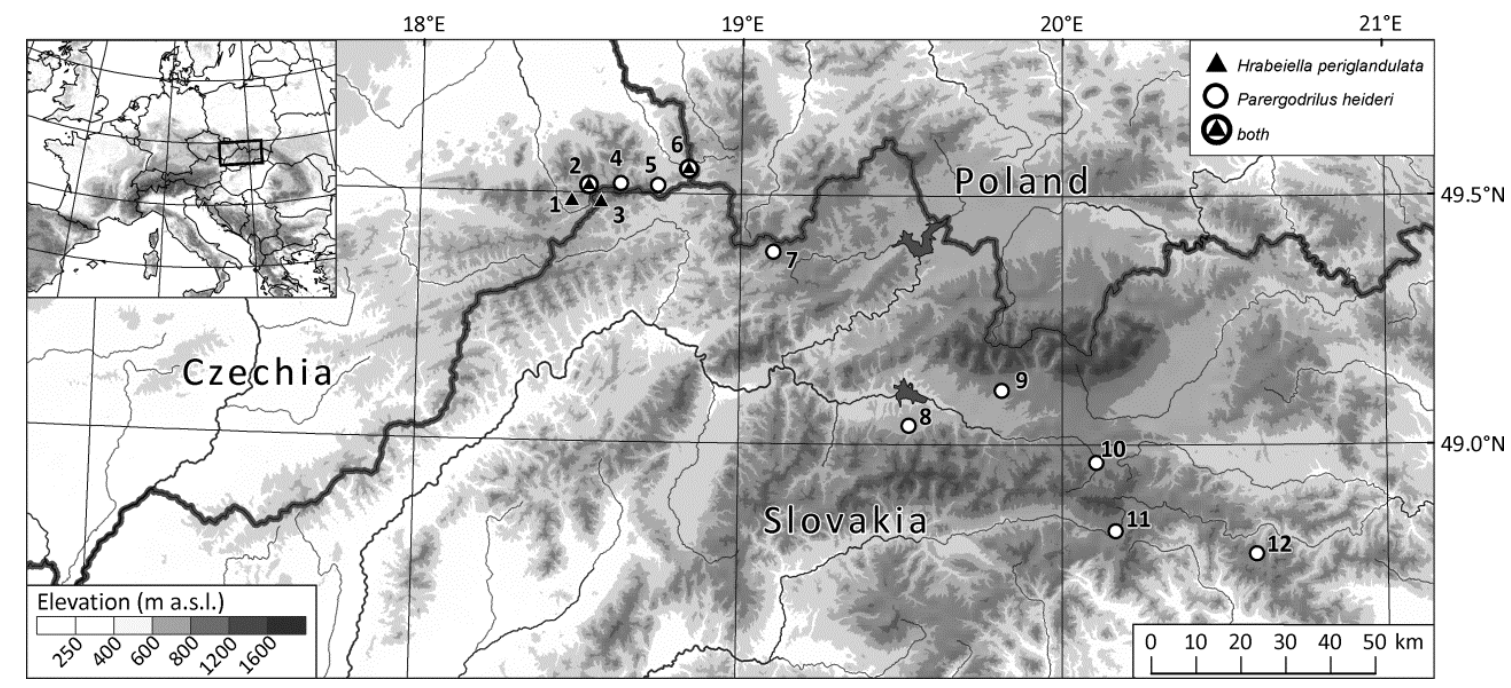

Figure 1. Map with localities of new records of Parergodrilus heideri (Parergodrilidae) and Hrabeiella periglandulata (Hrabeiellidae) in the Western Carpathians

country to the Volov Hills in the east. Furthermore we found $P$. heideri also at four sites in north-eastern Moravia, Czechia (15 specimens in total), one of which was situated in the Silesian Beskids (Slezské Beskydy) in the north-eastern corner of Czechia just at the border to Poland and the other two in the Moravian-Silesian Beskids (Moravskoslezské Beskydy), ca $1.6 \mathrm{~km}$ north and $2.5 \mathrm{~km}$ north-west of the border to Slovakia, respectively. Of the total number of $P$. heideri specimens, 31 were found in fen sediments $(68 \%$ in the $0-3 \mathrm{~cm}$ layer, $26 \%$ in the $3-6 \mathrm{~cm}$ layer) and 15 in grassland soil (87\% in the $0-3 \mathrm{~cm}$ layer, $13 \%$ in the $3-6 \mathrm{~cm}$ layer).

Hrabeiella periglandulata was found at three sites in Czechia (16 specimens, some with yolky eggs, several dead upon examination), situated in the Silesian and Moravian Beskids and at a single site within Slovakia (4 specimens), the latter situated in the Turzovka Highlands (Turzovská vrchovina), part of the western Beskids within the Outer Western Carpathians, $c a 1 \mathrm{~km}$ east of the border between Czechia and Slovakia. Specimens were exclusively obtained from soil samples, i.e. none from fen sediments. Vertical distribution in the upper $15 \mathrm{~cm}$ was rather even, with a moderate drop with depth (25\% both in the $0-3 \mathrm{~cm}$ and 3-6 $\mathrm{cm}$ layers, $20 \%$ in the $6-9 \mathrm{~cm}$ layer, $15 \%$ both in the $9-12 \mathrm{~cm}$ and $12-15 \mathrm{~cm}$ layers). The site in Slovakia differed from those in Czechia in that it was not a true grassland but a logged area of spruce forest, with some standing dead spruce trees and logging stumps, and rather sparsely afforested with young saplings of silver fir (Abies $a l b a$ ) and beech (Fagus sylvatica). The ground floor was overgrown with grass (predominantly Avenella flexuosa) and common bilberry (Vaccinium myrtillus), partially also mosses, with visible traces of red deer grazing. In general, the upper 3$6 \mathrm{~cm}$ of the soil profile were made up of an upper layer of decomposing grass and a lower layer of spruce needles in a more advanced stage of decomposition (F- and H-layers), followed by mineral soil, sometimes including rotten pieces of wood. The depth of the organic layer derived from forest litter varied, in some samples reaching down to ca $10 \mathrm{~cm}$ depth.

\section{DISCUSSION}

Neither of the two species has been reported from Slovakia before. In particular in the case of $H$. periglandulata, this might seem surprising, as there are records from all neighbouring countries, except the Ukraine, and also from north-eastern Romania (Dózsa-Farkas \& Schlaghamerský 2013). The closest previously published site of 
occurrence is situated in southern Poland (Dumnicka \& Rożen 2002), i.e. the western-most part of Niepołomice forest east of Cracow (Kraków), ca $135 \mathrm{~km}$ to the north-east from the present site. The closest locality in Czechia known prior to the present article was from a municipal forest of the city of Brno, $150 \mathrm{~km}$ to the west-southwest (Schlaghamerský \& Š́́dová 2009).

To our knowledge, $P$. heideri has neither been reported from Poland, nor from Lithuania, Latvia, Belarus, Ukraine or Russia. However, it was recently found in Estonia (Kõlli et al. 2015), which has shifted the eastern border of its known distribution area within Europe substantially to the east. From Czechia it had been reported only from the north of Bohemia (Chalupský 1992), close to the Polish border, whereas there were so far no records from Moravia. There is also no published record from Hungary, despite intensive research on soil-dwelling microannelids conducted there. However, in 2012 it was found in the Köszeg Mountains close to the Austrian border (unpublished record, Dózsa-Farkas, pers. com.). There are no records from the Balkans. Our find of $P$. heideri at Teplá Voda in the Volov Hills (eastern Slovakia) thus represents the second eastern-most published record within its known European range. Taking into account the species' confirmed occurrence in other regions of the Holarctic, i.e. eastern Asia and North America, the lacking records from many regions within Europe are most probably an effect of the lack of studies on soil-living microannelids (or, more generally, semiaquatic soil fauna).

Both $H$. periglandulata and $P$. heideri have been mostly found by enchytraeid researchers using some type of wet extraction from soil. Dry extraction methods, such as those used for microarthropods, do not allow to obtain intact specimens. Furthermore, tiny specimens belonging to taxa that are not the focus of the given researcher usually go unnoticed. Even in the case of studies on enchytraeids, the approach might differ among researchers. Whereas some have been paying attention to the "odd worm" in their samples, others might not have bothered spending time on spe- cimens not belonging to their group of interest. A fair number of studies on enchytraeids have been conducted in Poland, but few in the countries east of it. Before the present study Slovakia also remained almost unexplored in terms of its enchytraeid fauna, the only more comprehensive inventory being published by the Polish researcher Kasprzak (1986) on enchytraeid assemblages of forest sites in the Little Carpathians (Malé Karpaty), a small mountain range in the south-west of the country (see also Chalupský 1988).

Originally, $P$. heideri had been found in organic soil layers of montane beech forests and it was reported to avoid waterlogged soils (Reisinger 1925). In contrast, Rota et al. (2010) suggested that it might spread through waterlogged soils along hydrographic systems. Enchytraeids had been studied at four montane beech-fir forests in the Moravian-Silesian Beskids, rather close to the new localities of $P$. heideri presented above, but $P$. heideri was not found there (Schlaghamerský 2012). It has to be said that the scope of that study was rather limited in terms of the numbers of soil cores taken and the numbers of microannelids obtained. However, P. heideri was also not found during studies of enchytraeids and other microannelids in 10 grasslands and three broadleaved forests in the White Carpathians, including two montane beech forests, both close to the border to Slovakia (Schlaghamerský \& Kobetičová 2006, Schlaghamerský et al. 2007, Tajovský et al. 2008, Schlaghamerský 2010). Hrabeiella periglandulata was also not encountered during these studies.

This shows that albeit both polychaetes are surely more common than shown by the limited number of records, they are by no means omnipresent. Also in the present study both species were only found in a limited subset of the sampled sites. Records of $P$. heideri obtained during the present study confirm that it occurs indeed in terrestrial as well as semiaquatic habitats. It is worth mentioning that many enchytraeid individuals belonging to species that are generally considered terrestrial were also extract- 
ed from the studied fen sediments. The presence of $P$. heideri in substrates of $\mathrm{pH}$ values around 7 or even above is in line with the characterization given by Graefe \& Schmelz (1999), but we found the species also in soils with a $\mathrm{pH}$ as low as 4.6. As the numbers of evaluated soil or sediment cores from fens and grasslands were not identical, a direct evaluation of its habitat preferences (fen vs. grassland) is not possible. In the case of $H$. periglandulata, however, its complete lack from the wetland portions of the investigated sites indicates that this species avoids waterlogged substrate, though another reason might be the avoidance of higher $\mathrm{pH}$ values. Our fens were generally rich in minerals and of higher $\mathrm{pH}$ than the soils of the adjacent terrestrial habitats. This correlation of $\mathrm{pH}$ and moisture levels in our set of sites hampers a comparison of $\mathrm{pH}$ preferences between the two species.

Vertical distribution of both species in the soil or sediment profile probably matches the distribution of organic matter and, in particular in the case of the fen sediments, the availability of oxygen, but data on these variables are not available for the individual layers.

Table 1. Overview of localities, given from west to east, where Parergodrilus heideri (Parergodrilidae) and Hrabeiella periglandulata (Hrabeiellidae) were recorded in 2015 or 2016, with information on each site (habitat type and pH - two values correspond to records from two habitat types) and the numbers of specimens obtained (N P. $h$. and $\mathrm{N} H$. p., respectively, two values correspond to records from the two habitat types); numbering of localities corresponds to site numbers in Figure $1, \mathrm{CZ}$ and SK shows if the site is located in Czechia or Slovakia.

\begin{tabular}{|c|c|c|c|c|c|c|c|}
\hline Locality & $\begin{array}{l}\text { Latitude } \\
(\mathrm{N})\end{array}$ & $\begin{array}{l}\text { Longitude } \\
\text { (E) }\end{array}$ & $\begin{array}{l}\text { Geomorphological } \\
\text { Mesoregion }\end{array}$ & Habitat & $\begin{array}{c}\mathrm{pH} \\
\left(\mathrm{H}_{2} \mathrm{O}\right)\end{array}$ & $\begin{array}{c}\mathrm{N} \\
P . h\end{array}$ & $\begin{array}{c}\mathrm{N} \\
H . p\end{array}$ \\
\hline $\begin{array}{l}\text { 1) Podgruň } \\
\text { (CZ) }\end{array}$ & $49^{\circ} 29^{\prime} 10^{\prime \prime}$ & $18^{\circ} 28^{\prime} 23^{\prime \prime}$ & $\begin{array}{c}\text { Moravian-Silesian Beskids } \\
\text { (Moravskoslezské } \\
\text { Beskydy) }\end{array}$ & Pasture & 4.5 & - & 5 \\
\hline $\begin{array}{l}\text { 2) Obidová } \\
\text { (CZ) }\end{array}$ & 49³1'04”' & $18^{\circ} 31^{\prime} 26^{\prime \prime}$ & $\begin{array}{c}\text { Moravian-Silesian Beskids } \\
\text { (Moravskoslezské } \\
\text { Beskydy) }\end{array}$ & $\begin{array}{c}\text { Mineral-poor fen with } \\
\text { calcitolerant Sphagnum } \\
\text { spp./meadow }\end{array}$ & $7.7 / 4.3$ & $2 / 0$ & $0 / 10$ \\
\hline $\begin{array}{l}\text { 3) Jančíkovci } \\
\text { (SK) }\end{array}$ & 49²9’29”' & $18^{\circ} 33^{\prime} 00^{\prime \prime}$ & $\begin{array}{c}\text { Turzov Highland } \\
\text { (Turzovská vrchovina) }\end{array}$ & $\begin{array}{l}\text { Forest clearcut with } \\
\text { grass, moss and bilberry }\end{array}$ & 3.8 & - & 4 \\
\hline $\begin{array}{l}\text { 4) Kyčmol } \\
\text { (CZ) }\end{array}$ & $49^{\circ} 30^{\prime} 47^{\prime \prime}$ & $18^{\circ} 37^{\prime} 27^{\prime \prime}$ & $\begin{array}{c}\text { Moravian-Silesian Beskids } \\
\text { (Moravskoslezské } \\
\text { Beskydy) }\end{array}$ & Pasture & 4.6 & 1 & - \\
\hline $\begin{array}{l}\text { 5) Vřesová } \\
\text { stráň (CZ) }\end{array}$ & $49^{\circ} 30^{\prime} 16^{\prime \prime}$ & $18^{\circ} 44^{\prime} 44^{\prime \prime}$ & $\begin{array}{c}\text { Moravian-Silesian Beskids } \\
\text { (Moravskoslezské } \\
\text { Beskydy) }\end{array}$ & Pasture & 5.31 & 1 & - \\
\hline $\begin{array}{l}\text { 6) Bukovec } \\
\text { (CZ) }\end{array}$ & $49^{\circ} 32^{\prime} 57^{\prime \prime}$ & 18 $51^{\prime} 30^{\prime \prime}$ & $\begin{array}{c}\text { Moravian-Silesian Beskids } \\
\text { (Moravskoslezské } \\
\text { Beskydy) }\end{array}$ & $\begin{array}{l}\text { Mineral-rich fen/ } \\
\text { wet pasture }\end{array}$ & $8.5 / 5.5$ & $9 / 2$ & $0 / 1$ \\
\hline $\begin{array}{l}\text { 7) Vychylovka } \\
\text { (SK) }\end{array}$ & 49²3'03”' & $19^{\circ} 06^{\prime} 05^{\prime \prime}$ & $\begin{array}{l}\text { Kysuce Highland (Kysucká } \\
\text { vrchovina) }\end{array}$ & Tall herb meadow & 6.3 & 1 & - \\
\hline $\begin{array}{l}\text { 8) Chrastě at } \\
\text { Dúbrava (SK) }\end{array}$ & 4902'14”' & $19^{\circ} 31^{\prime} 31^{\prime \prime}$ & $\begin{array}{l}\text { Tatras: Liptov Basin } \\
\text { (Liptovská kotlina) }\end{array}$ & Mineral-rich fen & 7.4 & 11 & - \\
\hline $\begin{array}{l}\text { 9) Potôčky } \\
\text { (SK) }\end{array}$ & $49^{\circ} 06^{\prime} 29^{\prime \prime}$ & $19^{\circ} 48^{\prime} 44^{\prime \prime}$ & $\begin{array}{l}\text { Tatras: Tatra Foothills } \\
\text { (Tatranské podhorie) }\end{array}$ & Dry pasture & 4.9 & 1 & - \\
\hline $\begin{array}{l}\text { 10) Liptovská } \\
\text { Teplička (SK) }\end{array}$ & $48^{\circ} 57^{\prime} 47^{\prime \prime}$ & $20^{\circ} 06^{\prime} 16^{\prime \prime}$ & $\begin{array}{c}\text { Low Tatras } \\
\text { (Nízke Tatry) }\end{array}$ & Mineral-rich fen & 7.5 & 4 & - \\
\hline $\begin{array}{l}\text { 11) Meandre } \\
\text { Hrona (SK) }\end{array}$ & $48^{\circ} 49^{\prime} 34$ & $20^{\circ} 09^{\prime} 51^{\prime \prime}$ & $\begin{array}{c}\text { Low Tatras } \\
\text { (Nízke Tatry) }\end{array}$ & $\begin{array}{c}\text { Drier margin of alluvial } \\
\text { meadow }\end{array}$ & 6.6 & 7 & - \\
\hline $\begin{array}{l}\text { 12) Tichá } \\
\text { Voda (SK) }\end{array}$ & $48^{\circ} 46^{\prime} 50^{\prime \prime}$ & $20^{\circ} 35^{\prime} 50^{\prime \prime}$ & $\begin{array}{l}\text { Volov Hills (Volovské } \\
\text { vrchy) }\end{array}$ & $\begin{array}{l}\text { Mineral-poor fen with } \\
\text { calcitolerant Sphagnum } \\
\text { spp./ adjacent dry } \\
\text { grassland } \\
\end{array}$ & $6.7 / 4.9$ & $5 / 2$ & - \\
\hline
\end{tabular}


Acknowledgements - Our study was funded by the Czech Science Foundation, grant No. 15-15548S "Annelids of isolated micro-wetlands: from water to soil". We are thankful to our research team members Michal Horsák, Vendula Polášková, Jana Schenková, Standa Němejc (all Dept. of Botany and Zoology, Faculty of Science, Masaryk University) and Václav Pižl (Institute of Soil Biology, Biology Centre of the Czech Academy of Sciences, České Budějovice), who assisted in tasks such as site selection, logistics, field and lab work.

\section{REFERENCES}

CHALUPSKÝ, J. (1988): Czechoslovak Enchytraeids (Oligochaeta, Enchytraeidae). II. Catalogue of species. Věstnik Československé společnosti zoologické, 52: 81-95.

CHALUPSKÝ, J. (1992): Terrestrial Enchytraeidae (Oligochaeta) and Parergodrilidae (Polychaeta) from Sweden, with description of a new enchytraeid species. Zoologica Scripta, 21: 133150. doi: 10.1111/j.1463-6409.1992.tb00316.x

Christoffersen, M.L. (2012): Phylogeny of basal descendants of cocoon-forming annelids (Clitellata). Turkish Journal of Zoology, 36 (1): 95-119. doi: 10.3906/zoo-1002-27

DÓZSA-FARKAS, K. \& HONG, Y. (2010): Three new Hemienchytraeus species (Enchytraeidae, Oligochaeta, Annelida) from Korea, with first records of other enchytraeids and terrestrial polychaetes (Annelida). Zootaxa, 2406: 29-56. doi: 10.5281/zenodo. 194222

DÓZSA-FARKAS, K. \& SCHLAGHAMERSKÝ, J. (2013): Hrabeiella periglandulata (Annelida: „Polychaeta“ - do apparent differences in chaetal ultrastructure indicate the existence of several species in Europe? Acta Zoologica Academiae Scientiarum Hungaricae, 59 (2): 143-156.

DUMNICKA, E. \& RoŻEN, A. (2002): The first record of the terrestrial polychaete Hrabeiella periglandulata Pižl \& Chalupský, 1984, in Poland, with a note on anatomy and ecology. Fragmenta Faunistica, Warszawa, 45: 1-7.

GRAEFE, U. \& SCHMELZ, R. (1999): Indicator values, strategy types and life forms of terrestrial Enchytraeidae and other microannelids. In. SCHMELZ, R.M. \& SÜHLO, K. (Eds.) Newsletter on Enchytraeidae 6. Proceedings of the 3rd International Symposium on Enchytraeidae, Osnabrück, Germany. Universitätsverlag Rasch,Osnabrück, p. 59-67.
JÖRDENS, J., STRUCK, T. \& PURSChKE, G. (2004): Phylogenetic inference regarding Parergodrilidae and Hrabeiella periglandulata ('Polychaeta', Annelida) based on 18S rDNA, 28S rDNA and COI sequences. Journal of Zoological Systematics and Evolutionary Research, 42 (4): 270-280. doi: 10.1111/j.1439-0469.2004.00265.x

KASPRZAK, K. (1986): Enchytraeids (Oligochaeta, Enchytraeidae) of the Little Carpathians. In. NOSEK, J. (Ed.) The Soil Fauna of the Little Carpathians. Results of Research Program MAB, Bratislava: Institute of Experimental Biology and Ecology, Slovak Academy of Sciences, p. 71-75.

KÕLli, R., GRAEFE, U. \& TAMM, I. (2015): Abundance and species richness of microannelids in humus cover of Estonian forest soils. Journal of Agricultural Science, 26 (1): 24-29. (In Estonian with English Summary).

MARTÍNEZ-ANSEMIL, E. \& PARAPAR, J. (2009): Primera cita en la península Ibérica del poliqueto terrestre Parergodrilus heideri Reisinger, 1925 (Polychaeta, Parergodrilidae). Graellsia, 65 (2): 235 240. doi: 10.3989/graellsia.2009.v65.i2.152

PIŽL, V. \& CHALUPSKÝ, J. (1984): Hrabeiella periglandulata gen. et sp. n. (Annelida) - A curious worm from Czechoslovakia. Věstník československé Společnosti zoologické, 48: 291-295.

REISINGER, E. (1925): Ein landbewohnender Archiannelide. (Zugleich ein Beitrag zur Systematik der Archianneliden). Zeitschrift für Morphologie und Ökologie der Tiere, 3 (2/3): 197-254.

REISINGER, E. (1960): Die Lösung des ParergodrilusProblems. Zeitschrift für Morphologie und Ökologie der Tiere, 48: 517-544.

Rota, E., Nicola, F. DE, \& BARGAGLI, R. (2010): Parergodrilus heideri Reisinger, 1925 (Annelida: Polychaeta) from a holm oak wood in an extinct volcano of southern Italy. Zootaxa, 2687: 65-68.

SCHLAGHAMERSKÝ, J. (2010): The small annelids (Annelida: Enchytraeidae, Rhyacodrilinae, Aelosomatidae) in soils of three forests in the White Carpathians (Czech Republic). Acta Societatis Zoologicae Bohemicae, 74 (1-2): 103-115.

SCHLAGHAMERSKÝ, J. (2012): Terrestrial assemblages of small annelids (Clitellata: Enchytraeidae, Naididae) in beech-fir old growths of the Beskids Protected Landscape Area (Czechia) - results of a rapid assessment. Landbauforschung - vTi Agri- 
culture and Forestry Research, Sonderheft/Special Issue 137: 39-44.

SCHLAGHAMERSKÝ, J. \& KoBETIČOVÁ, K. (2006): The impact of cattle pasture on small annelids (Annelida: Enchytraeidae, Tubificidae, Aeolosomatidae) in grasslands of the White Carpathians (Czech Republic). European Journal of Soil Biology, 41: 305-309.

doi: 10.1016/j.ejsobi.2006.07.037

SCHLAGHAMERSKÝ, J. \& ŠíDOVÁ, A. (2009): Dynamics and vertical distribution of a Hrabeiella periglandulata (Annelida) population in South Moravia, Czech Republic. Pesquisa Agropecuária Brasileira, 44 (8): 917-921. doi: 10.1590/S0100-204X2009000800017

SCHLAGHAMERSKÝ, J., ŠíDOVÁ, A. \& PIŽL, V. (2007): From mowing to grazing: Does the change in grassland management affect soil annelid assemblages? European Journal of Soil Biology, 43 (1): 72-78. doi: 10.1016/j.ejsobi.2007.08.054
SChlaghamerskÝ, J. \& Frelich, J. E. (2012): First records of Parergodrilus heideri (Annelida: "Polychaeta") from North America. Zootaxa, 3498: 81-86.

Stoch, F., Gerecke, R., Pieri, V., Rossetti, G. \& SAMBUGAR, B. (2011): Exploring species distribution of spring meiofauna (Annelida, Acari, Crustacea) in the south-eastern Alps. Journal of Limnology, 70 (Suppl. 1): 65-76. doi: 10.3274/JL11-70-S1-05

TajovskÝ, K., Balík, V., HánĚl, L., Starý, J., SChlaghamerskÝ, J., Pižl, V., Stašıov, S. \& RESL, K. (2008): Vývoj půdní fauny na zatravňovaných plochách na lokalitě Výzkum / Soil fauna development at restored sites. In. JONGEPIEROVÁ, I. (Ed.) Louky Bílých Karpat /Grasslands of the White Carpathian Mountains, ZO ČSOP Bílé Karpaty, Veselí nad Moravou, p. 410-415.

WEIGERT, A. \& BLEIDORN, C. (2016): Current status of annelid phylogeny. Organisms Diversity \& Evolution, 16: 345-362. doi: 10.1007/s13127-016-0265-7 